Rev. Biol. Trop. 36 (2B): 541-544, 1988.

\title{
COMUNICACIONES
}

\section{A survey of the meiofauna of an Eastern Tropical Pacific intertidal mud flat*}

José A. Vargas

Centro de Investigación en Ciencias del Mar y Limnología (CIMAR), Universidad de Costa Rica. San José, Costa Rica.

(Rec. 15-XII-1987. Acep. 15-II-1988)

\begin{abstract}
Resumen: Se estudió, durante trece meses (1984-1985), la meiofauna de la playa fangosa (promedio: $32 \%$ limo + arcilla, $2.1 \%$ materia orgánica) en el Golfo de Nicoya $\left(10^{\circ} \mathrm{N}, 85^{\circ} \mathrm{W}\right)$, Costa Rica. Se recolectó muestras con un cilindro de $5.3 \mathrm{~cm}^{2}$ de área hasta una profundidad de $6 \mathrm{~cm}$ en el sedimento, las que fueron preservadas en una solución al $5 \%$ de formaldehido en agua de mar teñida con rosado de Bengala y, finalmente, lavadas a través de tamices de 500 y 63 micrómetros de abertura del poro. Se extrajo a los organismos manualmente y bajo observación con un microscopio $(30 \mathrm{X})$. Se analizó 39 muestras ( $3 / \mathrm{fecha})$, las cuales contenían un total de 50,086 individuos, con un promedio mensual de 1,285 $\pm 526\left(\sim 2.4 \pm 1.0 \times 10^{6}\right.$ individuos $\left./ \mathrm{m}^{2}\right)$. Los nemátodos representaron $82 \%$ del total, seguidos por los foraminiferos $(6.1 \%)$, copépodos $(4.2 \%)$ y ostrácodos $(3.7 \%)$. La temperatura y la salinidad del agua (marea baja) oscilaron entre $31^{\circ} \mathrm{C} \mathrm{y} 40^{\circ} \mathrm{C}$., y entre $30 \%$ y $34^{0} \% 0$, respectivamente. Hay asociaciones positivas entre el porcentaje de limo + arcilla y las abundancias de los organismos. Además, se encontró diferencias significativas entre las abundancias mensuales. Sin embargo, no se encontró estacionalidad (estación seca vs. estación lluviosa) en la abundancia.

Se especula que la densidad alta observada se debe tanto a aspectos metodológicos (tamaño del tamiz y método de preservado de la muestra), como a la disponibilidad de alimento en el sedimento. Las variaciones espaciales y temporales de abundancia se podrían relacionar con las variaciones de ciertos parámetros ambientales, actividad de depredadores y a posibles interacciones de la meiofauna con la abundante macrofauna. Se sugiere que algunas características reproductivas de la meiofauna podrán influir en la aparente falta de estacic nalidad de la abundancia.
\end{abstract}

The permanent meiofauna has been defined as a group of small metazoans mostly passing a 500 micron mesh, which by their size, number, generation time and adaptations can conveniently be considered separately from larger members of the benthos (McIntyre 1969). The lower meiofaunal size limit is generally set by the use of a 63 micron mesh screen (see Guzmán et al. 1987).

In Costa Rica the study of intertidal meiofauna was initiated by De la Cruz and Vargas (1986-1987) who studied the abundance and vertical distribution of this group at the Punta Morales (mean tidal range: $2.3 \mathrm{~m}$ ) mud flat in the Gulf of Nicoya, Pacific coast of Central America (Figure 1). These papers, in addition to that by Guzmán et al. (1987), appear to be the only reports on meiofauna from the Eastern Tropical Pacific.

* Contribution 128 of CIMAR.
In this note I report the results of a parallel meiofaunal survey conducted at the Punta Morales mud flat as part of a broader study of the benthic community (see Vargas 1987, 1988). From February of 1984 through February of 1985, three cores (core area: $5.3 \mathrm{~cm}^{2}, 6 \mathrm{~cm}$ deep) were collected monthly and randomly from a $484 \mathrm{~m}^{2}$ area of the mud flat, and preserved in a 5\% solution of formaldehyde in sea water stained with Rose Bengal. The cores were washed on 500 and 63 micron mesh sieves, and organisms from the smaller sieve were extracted and counted under a dissection microscope $(30 \mathrm{X})$. Two sediment samples were collected per date for grain size, and for organic matter content (by combustion at $550^{\circ} \mathrm{C}$ ), analyzes. Salinity and water temperature were recorded at the time of collection of samples. All cores were taken at low tide and during the late morning hours.

Water temperature at low tide ranged from $31^{\circ} \mathrm{C}$ (August, September) to $40^{\circ} \mathrm{C}$ in April. 


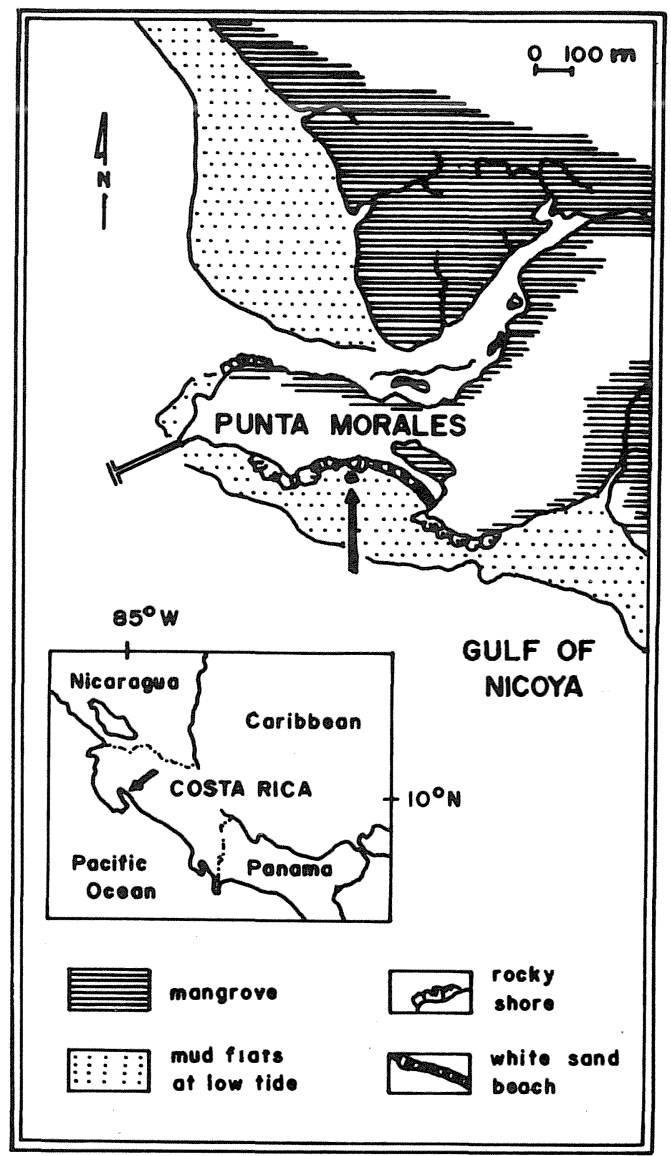

Figure 1. Punta Morales peninsula, Gulf of Nicoya, Costa Rica. Arrows point to the location of the study site.

Salinity ranged from $30 \%$. (October, November) to $34^{\circ} / 00$ (April). On the average sediments at the site were characterized by $65 \%$ sand, $32 \%$ silt + clay, and $2.1 \%$ organic matter content. The percentage of sand varied from 53.8 (June) to 73.9 (August); silt + clay varied from $31.1 \%$ (August) to $44 \%$ (June), and organic matter content from $1.3 \%$ (February, March, 1984) to $2.9 \%$ (February, 1985).

The 39 cores analyzed for meiofauna yielded a total of 50,086 individuals, and a monthly mean ( \pm 1 SD) of $1.285 \pm 526$ organisms (Figure 2) This value represents a mean density of $\sim 2.4 \pm 1.0 \times 10^{6}$ ind. $/ \mathrm{m}^{2}$ No clear trend in meiofaunal abundance was evident during the sampling period. A sharp peak of abundance, however, was observed during June (Figure 2). Four groups: Nematoda, Foraminifera, Copepoda, and Ostracoda accounted for a mean of $96 \%$ of the meiofauna. Nematodes were the

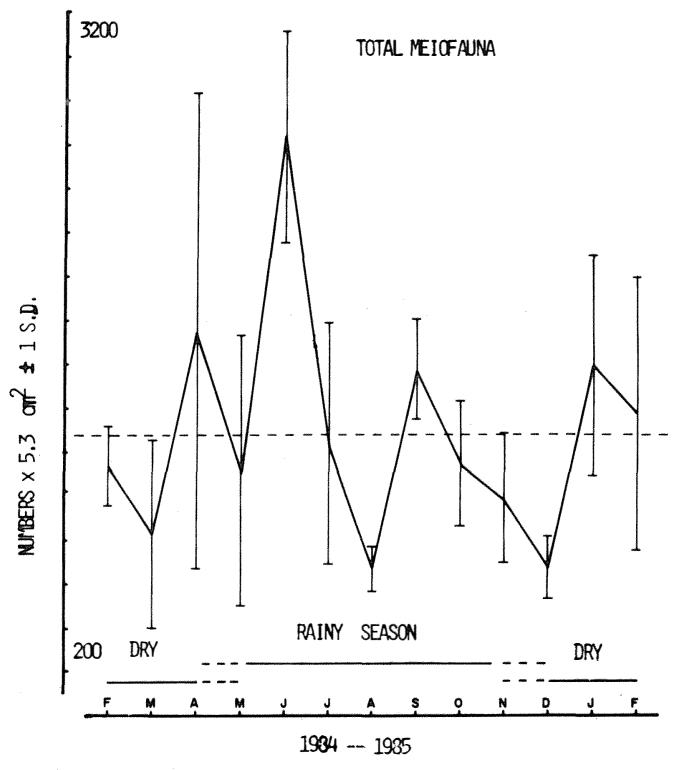

Figure 2. Mean $(n=3)$ number of individuals $( \pm 1$

standard deviation) of all meiofaunal organisms collected by coring. Dashed line indicates mean number of individuals over the sampling period. Punta Morales intertidal mud flat, Gulf of Nicoya, Costa Rica.

most common organisms representing $82 \%$ of the total. Foraminifera and Copepoda constituted 6.1 and $4.2 \%$ of the total, respectively. Ostracoda contributed $3.7 \%$. The mean number of organisms $( \pm S D)$ found per date for each of these groups is included in Table 1. Other organisms collected (including members of the temporary meiofauna) were: 1,303 nauplii, 90 cumaceans (manca stage), and 29 kinorhynchs. Other groups appearing sporadically and at low abundances were juveniles of: bivalves, gastropods, ophiuroids, and polychaete worms. Oligochaetes and flat worms (Turbellaria) were collected occasionally.

Spearman's rho rank correlation tests revealed significant associations between the percentage of silt and clay and total meiofauna (significance $=0.01)$, nematodes $(0.01)$, foraminiferans (0.04), copepods (0.05), and ostracods (0.001). These correlations were positive. Ostracods also showed a significant positive association with salinity (0.01). Analysis of Variance (ANOVA) indicated that highly significant differences exist between dates for total meiofauna, Nematoda, Foraminifera, Copepoda, and Ostracoda. 
TABLE 1

Mean number \pm 1 standard deviation of nematodes, foraminiferans, benthic copepods, and ostracods collected monthly at the Punta Morales intertidal mud flat, Gulf of Nicoya, Costa Rica, from February 1984 through February 1985.

\begin{tabular}{|c|c|c|c|c|}
\hline & Nematoda & Foraminifera & Copepoda & Ostracoda \\
\hline February $22 *$ & $913 \pm 186$ & $115 \pm 22$ & $13 \pm 10$ & $58 \pm 16$ \\
\hline March 20 & $705 \pm 396$ & $49 \pm 24$ & $13 \pm 1$ & $41 \pm 3$ \\
\hline April 17 & $1499 \pm 1014$ & $21 \pm 17$ & $17 \pm 3$ & $185 \pm 83$ \\
\hline May $16 *$ & $1009 \pm 595$ & $61 \pm 30$ & $2 \pm 3$ & $36 \pm 20$ \\
\hline June $19 *$ & $2376 \pm 504$ & $164 \pm 63$ & $7 \pm 4$ & $72 \pm 10$ \\
\hline July 19 & $1112 \pm 487$ & $47 \pm 15$ & $32 \pm 30$ & $26 \pm 14$ \\
\hline August 14 & $612 \pm 101$ & $55 \pm 27$ & $1 \pm 1$ & $5 \pm 3$ \\
\hline September 10 & $1420 \pm 312$ & $44 \pm 37$ & $50 \pm 17$ & $22 \pm 12$ \\
\hline October 26 & $868 \pm 286$ & $162 \pm 88$ & $44 \pm 27$ & $41 \pm 13$ \\
\hline November 24 & $843 \pm 264$ & $55 \pm 14$ & $45 \pm 27$ & $11 \pm 3$ \\
\hline December 26 & $536 \pm 161$ & $38 \pm 9$ & $43 \pm 21$ & $13 \pm 6$ \\
\hline January 24 & $1158 \pm 414$ & $98 \pm 30$ & $182 \pm 110$ & $49 \pm 6$ \\
\hline February 21 & $708 \pm 192$ & $116 \pm 66$ & $250 \pm 225$ & $50 \pm 48$ \\
\hline
\end{tabular}

* Based on raw data from De la Cruz and Vargas (1987). All values are means of 3 replicates. Core area : $5.3 \mathrm{~cm}^{2}$. All cores collected to a depth of $6 \mathrm{~cm}$ into the sediment.

Mean meiofaunal abundance in Punta Morales sediments $\left(\sim 2.4 \times 10^{6}\right.$ ind. $\left./ \mathrm{m}^{2}\right)$ ranks among the highest reported for tropical intertidal environments. De la Cruz and Vargas (1986) found an abundance range at the site of 0.65 to 1.08 $\mathrm{x} 10^{6}$ ind. per $\mathrm{m}^{2}$ during a three month survey conducted in 1983, and a mean of 2.17 million per $\mathrm{m}^{2}$ during a seven month study in 1984 (De la Cruz and Vargas 1987). McIntyre (1969) reports an abundance range of 0.42 to $3.81 \times 10^{6}$ individuals $/ \mathrm{m}^{2}$ from intertidal areas in the Vellar estuary (India, $11^{\circ} \mathrm{N}$ ). In these studies a 63 micron mesh was used to separate the meiofauna from the microfauna (in addition to formalin preservation and Rose Bengal staining). Few ecologists have used these methods, however, with the result that meiofaunal data are difficult to compare. For instance, McIntyre (1969) lists densities of total meiofauna ranging from 0.01 to 10.2 million individuals per $\mathrm{m}^{2}$ found in 17 intertidal studies worldwide in which different methodologies were used to collect, preserve, and extract the organisms. Rudnick et al. (1985) reviewed more than forty papers dealing with subtidal meiofaunal research worldwide and found that only five reported the use of a 63 micron mesh sieve. In these studies meiofaunal densities ranged from 0.4 to 2.5 million per $\mathrm{m}^{2}$. Smaller mesh openings ( 40 to 45 microns) yielded densities ranging from 0.36 to 17 million, and mesh sizes greater than 100 microns yielded between 0.01 and 0.7 million. Moreover, in nine out of eleven papers in which densities in excess of two million were reported, formalin preservation and Rose Bengal staining were used. Thus, Rudnick et al. (1985) concluded that estimates of meiofaunal abundance are partially influenced by methodology and emphasized that greater accuracy is attained with formalin preservation and Rose Bengal staining than with other methods. Other factors, in addition to methodology, might have con- 
tributed to the finding of high meiofaunal densities in Punta Morales. The Gulf of Nicoya is a productive tropical estuary (see references in Vargas 1987, 1988). Part of this production may settle, perhaps becoming readily usable food for the benthos. In addition, in situ production by phytobenthos might be important at the mud flat as indicated by a high abundance of pennate diatoms in the sediment. These areas of research deserve further attention.

The diversity of major taxonomic groups in Punta Morales is similar to that found in other intertidal environments worldwide. This topic is discussed in more detail by De la Cruz and Vargas $(1986,1987)$.

Spatial patchiness was high at the mud flat as indicated by the standard deviations associated with monthly means for total meiofauna and the four main groups (Table 1). More formal measures of patchiness, such as the varianceto-mean ratio, revealed significant (Chi-square) departures from randomness. Spatial and temporal variability might be associated with fluctuations of certain environmental variables like the percentage of silt and clay in the sediments. McIntyre (1969) concluded that the intertidal distribution of meiofauna is influenced in part by the grain size of the sediments which affects the interstitial space, water content, and food availability. The ultimate cause of meiofaunal population changes at the site, however, may be a complex interaction between environmental (e.g. degreee of exposure at low tide, salinity variations) and biological (e.g. bioturbation of sediments, fish predation) factors. Fitzhugh and Fleeger (1985) report that gobiid fish predation influences density and depth distribution of meiobenthos. Based on examination of gut contents from several gobiids collected in Punta Morales, I know that Gobionellus sagitulla (Günther) preys on meiofauna. In addition, other macrofauna-meiofauna interactions might be intense in view of the relatively high density of macrofauna $\left(14,798\right.$ ind. $\left./ \mathrm{m}^{2}\right)$ reported for the site (Vargas 1988). This area of research also deserves future attention.

No significant seasonal (dry vs rainy) difference in total meiofauna, and in the abundance of each of the four main groups, was detected for Punta Morales. Cumaceans (manca stage) and kinorhynchs, however, were collected more frequently during the dry season. In contrast to the macrofauna, some reproductive characteristics of the meiofauna, such as a ge- neral reduction of larval stages, extended spawning periods, brood protection, and production of a small number of large gametes (McIntyre 1969), perhaps make the detection of seasonal changes in abundance more difficult that for the macrofauna. Seasonal changes of the macrofauna at the site have been reported by Vargas (1987).

\section{ACKNOWLEDGEMENTS}

This paper was extracted from the first chapter of a Ph. D. thesis submitted to the University of Rhode Island (U.S.A.). In Costa Rica, Elba de la Cruz and Renán Chaves assisted with the laboratory and computer work, respectively. This research was supported by an AID loan to CONICIT (Costa Rica), and by the Universidad de Costa Rica (Project 808-85-042). Research was facilitated by access to the Laboratorio de Investigaciones Marinas (L.I.M.) in Punta Morales.

\section{REFERENCES}

De la Cruz, Elba \& J.A. Vargas. 1986. Estudio preliminar de la meiofauna de la playa fangosa de Punta Morales, Golfo de Nicoya, Costa Rica, Brenesia 25-26: 89-97.

De la Cruz, Elba \& J.A. Vargas. 1987. Abundancia y distribución vertical de la meiofauna en la playa fangosa de Punta Morales, Golfo de Nicoya, Costa Rica. Rev. Biol. Trop. 35(2): 363-367.

Fitzhugh, G.R. \& J.W. Fleeger. 1985. Goby (Pisces: Gobiidae) interactions with meiofauna and small macrofauna. Bull. Mar. Sci. 36: 436-444.

Guzmán, H., Vilma Obando \& J. Cortés. 1987. Meiofauna associated with a Pacific coral reef in Costa Rica.Coral Reefs 6: 107-112.

McIntyre, A.D. 1969. Ecology of Marine Meiobenthos. Biol. Rev. 44: 255-290.

Rudnick, D.T., R. Elmgren \& J.B. Frithsen. 1985. Meiofaunal prominence and benthic seasonality in a coastal marine ecosystem. Oecologid 67: 157-168.

Vargas, J.A. 1987. The benthic community of an Intertidal mud flat in the Gulf of Nicoya, Costa Rica. Description of the community. Rev. Biol. Trop. 35 (2): 299-316.

Vargas, J.A. 1988. Community structure of macrobenthos and the results of macropredator exclusion on a tronical intertidal mud flat. Rev. Biol. Trop. 36 (2A): 287-308. 